\title{
Particle length of silages affects apparent ruminal synthesis of B vitamins in lactating dairy cows
}

\author{
D. S. Castagnino, ${ }^{\star} \dagger$ K. L. Kammes, $\ddagger$ M. S. Allen, $\ddagger$ R. Gervais, $†$ P. Y. Chouinard, $†$ and C. L. Girard ${ }^{* 1}$ \\ *Agriculture and Agri-Food Canada, Sherbrooke Research and Development Centre, 2000 College, Sherbrooke, Québec, Canada, J1M 0C8 \\ †Département des sciences animales, Université Laval, 2425 rue de l'Agriculture, Québec, Québec, Canada, G1V 0A6 \\ ‡Department of Animal Science, Michigan State University, East Lansing 48824-1225
}

\section{ABSTRACT}

Effects of particle length of silages on apparent ruminal synthesis (ARS) and postruminal supply of $\mathrm{B}$ vitamins were evaluated in 2 feeding trials. Diets containing alfalfa (trial 1) or orchardgrass (trial 2) silages, chopped to either $19 \mathrm{~mm}$ (long cut, LC) or $10 \mathrm{~mm}$ (short cut, SC) theoretical particle length, as the sole forage were offered to ruminally and duodenally cannulated lactating Holstein cows in crossover design experiments. Forages chopped to a theoretical particle length of 19 and $10 \mathrm{~mm}$ had mean particles sizes of 14.1 and $8.1 \mathrm{~mm}$, respectively, in trial 1, and 15.3 and $11.3 \mathrm{~mm}$, respectively, in trial 2 . Trial 1 was conducted with 13 multiparous cows in two 19-d treatment periods; both diets contained approximately $20 \%$ forage neutral detergent fiber (NDF), $25 \%$ total NDF, and forage-to-concentrate ratios were approximately 47:53. Trial 2 was conducted with 15 cows in two 18-d treatment periods; both diets contained approximately $23 \%$ forage NDF, $28 \%$ total NDF, and had a forage-toconcentrate ratio of 50:50. Thiamine, riboflavin, niacin, vitamin $\mathrm{B}_{6}$, folates, and vitamin $\mathrm{B}_{12}$ were measured in feed and duodenal content. Daily ARS was calculated as the duodenal flow minus the intake. In trial 1, daily intake of individual $\mathrm{B}$ vitamins was increased with the $\mathrm{LC}$ diet, but ARS of thiamine, riboflavin, vitamin $\mathrm{B}_{6}$, and folates was reduced. In trial 2, except for folates, intakes of the other B vitamins were decreased with the LC diets, whereas ARS of riboflavin, niacin, and vitamin $B_{6}$ was increased. Daily ARS of thiamine, riboflavin, niacin, and vitamin $B_{6}$ were correlated negatively with their intake, suggesting that ruminal bacteria reduced their synthesis when dietary supply increased. Microbial activity could have also reduced degradation of thiamine, riboflavin, and niacin, which is supported by (1) the negative correlation between ARS of these

Received April 5, 2016.

Accepted April 19, 2016.

${ }^{1}$ Corresponding author: Christiane.Girard@agr.gc.ca vitamins and ruminal $\mathrm{pH}$ or microbial $\mathrm{N}$ duodenal flow; and (2) the positive correlation between ARS and ruminal concentrations of volatile fatty acids. Folate ARS followed the opposite correlation pattern. Nevertheless, in spite of differences in intake and ARS, with both forages, decreasing particle length of silages had limited effects on the amounts of $\mathrm{B}$ vitamins reaching the sites of absorption in the small intestine of dairy cows.

Key words: ruminal synthesis, B vitamin, dairy cow, particle length, silage

\section{INTRODUCTION}

The amount of $\mathrm{B}$ vitamins reaching the intestinal sites of absorption is largely influenced by DMI, nutritional composition of diets, as well as vitamin microbial synthesis and degradation in the rumen. Increasing DMI of grain-fed steers has been shown to increase duodenal flow (DF) of thiamine, niacin, vitamin $\mathrm{B}_{6}$, and vitamin $\mathrm{B}_{12}$ (Zinn et al., 1987). In lactating dairy cows, Beaudet et al. (2016) reported that increasing dietary $\mathrm{N}$ concentration increased $\mathrm{DF}$ of vitamin $\mathrm{B}_{6}$ and folates, whereas high-fiber diets increased apparent ruminal synthesis (ARS) and DF of vitamin $\mathrm{B}_{12}$ compared with high-starch diets. Results from previous studies suggested that changes in forage characteristics are one of the most important sources of variation on B-vitamin supply to the duodenum. Castagnino et al. (2014) noted that delaying the harvest of alfalfa or grass resulted in a greater dietary supply of thiamine. More recently, Castagnino et al. (2016), while evaluating the effects of forage family, reported that diets based on orchardgrass silage increased ARS of thiamine and vitamin $\mathrm{B}_{6}$ compared with diets based on alfalfa silage. Such effects are likely due to differences in concentration and the rate and extent of digestion of fiber (Van Soest, 1982). Nevertheless, in the studies of Castagnino et al. (2014, 2016), differences in forage composition were possibly confounded, at least partially, with changes in the proportions of the other ingredients used in the experimental diets to achieve similar nutrient composition. 
Particle length (PL) can affect ruminal digestion parameters because reducing PL can increase passage rate in the rumen (Dixon and Milligan, 1985) and decrease ruminal $\mathrm{pH}$ due to limited buffer capacity caused by shorter rumination time (Beauchemin et al., 2003). Although PL has been established as an important factor in ruminant nutrition, information is lacking about its effect on B-vitamin synthesis in the rumen.

We hypothesized that the effects of PL on rumen parameters (such as $\mathrm{pH}$ and microbial activity) already evaluated and reported in our studies (Kammes et al., 2012; Kammes and Allen, 2012) will affect B-vitamin supply to dairy cows. The objective of the present study was to determine the effect of diets based on alfalfa and orchardgrass silages chopped at different PL (long- or short-cut) on B-vitamin ARS and DF in lactating dairy cows.

\section{MATERIALS AND METHODS}

Experimental procedures of the 2 reported studies were conducted on cows from the Dairy Cattle Teaching and Research Center, and approved by the Institutional Animal Care and Use Committee at Michigan State University (East Lansing, MI). Prior to calving, cows were equipped with a ruminal cannula and a duodenal gutter-type $\mathrm{T}$ cannula, approximately $10 \mathrm{~cm}$ distal to the pylorus. Surgeries were performed at the Department of Large Animal Clinical Sciences, College of Veterinary Medicine, Michigan State University. Experimental procedures, measurements, and analyses were described in detail by Kammes et al. (2012, trial 1) and Kammes and Allen (2012, trial 2).

\section{Treatments and Cows}

Experimental treatments were diets containing alfalfa (Medicago sativa L.; trial 1) or orchardgrass (Dactylis glomerata L.; trial 2) chopped to a theoretical PL of (a) $19 \mathrm{~mm}$ (long cut, LC) or (b) $10 \mathrm{~mm}$ (short cut, SC), as the sole forage. Measured mean particles sizes were 14.1 and $8.1 \mathrm{~mm}$, respectively, in trial 1, and 15.3 and $11.3 \mathrm{~mm}$, respectively, in trial 2 (Table 1 ). Cows were fed diets as a TMR offered once daily $(1130 \mathrm{~h})$ at $110 \%$ of expected intake.

Trial 1. Thirteen multiparous cows were assigned randomly to treatment sequence in a crossover design with a 14-d preliminary period followed by two 19-d treatment periods. Both experimental diets contained approximately $20 \%$ forage NDF, $25 \%$ total NDF, and the forage-to-concentrate ratios were approximately 47:53.

Trial 2. Fifteen multiparous cows were assigned randomly to treatment sequence in a crossover design with a 14-d preliminary period followed by two 18-d treatment periods. Both experimental diets contained approximately $23 \%$ forage NDF, $28 \%$ total NDF, and had a forage-to-concentrate ratio of 50:50.

\section{Sample and Data Collection}

Individual feed intake was recorded daily. At each period, samples of all dietary ingredients were collected from d 13 to 17 (trial 1) or from d 11 to 15 (trial 2) and mixed into one sample. During this collection period, duodenal digesta samples were collected every $15 \mathrm{~h}$ so that 8 samples were taken for each cow in each period, representing every $3 \mathrm{~h}$ of a 24 -h period to account for nycthemeral variation. All samples were stored at $-20^{\circ} \mathrm{C}$ before processing.

\section{Laboratory Analyses}

Frozen duodenal digesta samples were chopped finely using a commercial food processor (84142 food cutter, Hobart Manufacturing Co., Troy, $\mathrm{OH}$ ) and a representative subsample was lyophilized. All dried samples were ground with a Wiley mill (1-mm screen, Arthur H. Thomas, Philadelphia, PA). Methods used to determine $\mathrm{DM}, \mathrm{OM}$, ash, NDF, indigestible NDF, and starch in feed and duodenal digesta samples as well as digestive parameters (ruminal digestion of true OM, NDF, and starch, ruminal $\mathrm{pH}$ and VFA profile, and DF of DM, microbial N, and indigestible NDF) were described by Kammes et al. (2012, trial 1) and Kammes and Allen (2012, trial 2).

Concentrations of B vitamins in feed and duodenal digesta were determined at the Sherbrooke Research and Development Centre (Agriculture and Agri-Food Canada, Sherbrooke, QC, Canada). Thiamine, riboflavin, niacin, and vitamin $\mathrm{B}_{6}$ were quantified by HPLC (Varian ProStar, Lake Forest, CA) equipped with a solvent delivery system (model 210), an autosampler (model 410), and a fluorescence detection system (model 363) as described by Castagnino et al. (2016). Folates were determined with a microbiological microtiter plate test (VitaFast Folic Acid, R-Biopharm Inc., Marshall, $\mathrm{MI}$ ) and vitamin $\mathrm{B}_{12}$ was analyzed by radio-assay [SimulTRAC-S Vitamin $\mathrm{B}_{12}\left({ }^{57} \mathrm{Co}\right) /$ Folate $\left({ }^{125} \mathrm{I}\right)$, MP Biomedicals, Solon, $\mathrm{OH}]$ as described by Castagnino et al. (2016). Cobalt concentration in experimental diets was determined by atomic absorption spectrometry with flame stoichiometric air-acetylene at $240.7 \mathrm{~nm}$ based on an adaptation of the method of Bellanger (1988). Aliquots of $1.0 \mathrm{~g}$ of feed were dry-ashed for $18 \mathrm{~h}$ at $500^{\circ} \mathrm{C}$ with a hold at $350^{\circ} \mathrm{C}$ for $1 \mathrm{~h}$. Dry-ashed samples were dissolved in $2.0 \mathrm{M} \mathrm{HCl}$ and homogenized in an ultrasonic bath (Ultrasonic Cleaners, $40 \mathrm{kHz}$, 
Cole-Parmer, Montréal, QC, Canada) for $30 \mathrm{~min}$, and if needed, further dilutions with 1.0 M HCl. Samples were analyzed in duplicate (except for folates, which were analyzed in triplicate), and a coefficient of variation of less than $10 \%$ was accepted between replicates.

\section{Calculations and Statistical Analyses}

B-vitamin concentrations in the TMR were the summation of B-vitamin concentration of each ingredient (Table 2) multiplied by the proportion of this ingre- dient in the TMR, on a DM basis. Daily intakes of each vitamin were calculated as the concentration of the vitamin in the TMR multiplied by the amount of TMR ingested, on a DM basis. Dry matter DF was estimated using indigestible NDF as a flow marker as described by Kammes et al. (2012; trial 1) and Kammes and Allen (2012; trial 2). Duodenal flow of vitamins was calculated as B-vitamin concentrations in duodenal digesta multiplied by the daily DM flowing through the duodenum. Daily ARS was calculated as the DF minus the intake.

Table 1. Ingredients, nutrient composition, and B-vitamin concentrations of the 2 treatment diets containing alfalfa or orchardgrass, both chopped to 2 different particle lengths ${ }^{1}$

\begin{tabular}{|c|c|c|c|c|}
\hline \multirow[b]{2}{*}{ Item } & \multicolumn{2}{|c|}{ Alfalfa } & \multicolumn{2}{|c|}{ Orchardgrass } \\
\hline & Long & Short & Long & Short \\
\hline \multicolumn{5}{|l|}{ Ingredient, $\%$ of DM } \\
\hline Alfalfa silage & $46.3^{2}$ & $47.0^{3}$ & - & - \\
\hline Orchardgrass silage & - & - & $49.8^{4}$ & $49.7^{5}$ \\
\hline Dry ground corn & 36.4 & 36.0 & 38.4 & 37.9 \\
\hline Soybean meal $48 \% \mathrm{CP}$ & 8.03 & 7.84 & 2.89 & 3.45 \\
\hline SoyPlus ${ }^{6}$ & 4.02 & 3.92 & 3.39 & 3.39 \\
\hline Vitamin and mineral $\operatorname{mix}^{7,8}$ & 4.68 & 4.68 & 3.97 & 3.97 \\
\hline Limestone & 0.39 & 0.39 & 1.60 & 1.60 \\
\hline Salt & 0.19 & 0.19 & - & - \\
\hline \multicolumn{5}{|l|}{ Nutrient } \\
\hline DM, \% as fed & 58.8 & 53.5 & 40.8 & 46.5 \\
\hline OM, \% of DM & 93.4 & 92.8 & 90.0 & 90.1 \\
\hline $\mathrm{NDF}, \%$ of DM & 24.5 & 25.5 & 28.3 & 27.4 \\
\hline Forage NDF, $\%$ of DM & 19.6 & 20.7 & 23.3 & 22.5 \\
\hline Indigestible NDF, $\%$ of DM & 15.5 & 14.6 & 8.20 & 7.90 \\
\hline Starch, \% of DM & 30.8 & 30.5 & 29.8 & 29.5 \\
\hline $\mathrm{CP}, \%$ of DM & 19.3 & 18.9 & 17.9 & 17.9 \\
\hline Total cobalt, mg/kg of DM & 1.21 & 1.16 & 1.25 & 1.24 \\
\hline \multicolumn{5}{|c|}{ B-vitamin concentration, $\mathrm{mg} / \mathrm{kg}$ of DM } \\
\hline Thiamine & 3.58 & 3.15 & 2.72 & 2.78 \\
\hline Riboflavin & 77.9 & 71.4 & 42.7 & 70.9 \\
\hline Niacin $^{9}$ & 104 & 97.0 & 34.2 & 47.2 \\
\hline Vitamin $\mathrm{B}_{6}{ }^{10}$ & 7.72 & 6.72 & 4.45 & 9.11 \\
\hline Folates & 0.377 & 0.313 & 0.286 & 0.228 \\
\hline Vitamin $B_{12}$ & 0.005 & 0.003 & 0.005 & 0.010 \\
\hline Mean particle size, $\mathrm{mm}$ & 14.1 & 8.1 & 15.3 & 11.3 \\
\hline
\end{tabular}

${ }^{1}$ Adapted from Kammes et al. (2012) and Kammes and Allen (2012).

${ }^{2} \mathrm{DM}, 42.2 \%$ (as fed); and OM, $92.0 \%$; NDF, $42.3 \%$; indigestible NDF, $29.1 \%$; starch, $1.89 \%$; CP, $20.4 \%$ (DM basis); fermentation $=\mathrm{pH}, 4.62$; acetic acid, $1.29 \%$ of DM; ammonia, $6.32 \mathrm{mM}$.

${ }^{3} \mathrm{DM}, 36.9 \%$ (as fed); and OM, 90.9\%; NDF, $44.0 \%$; indigestible NDF, $26.8 \%$; starch, $1.92 \%$; CP, $19.6 \%$ (DM basis); fermentation $=\mathrm{pH}, 4.42$; acetic acid, $1.49 \%$ of DM; ammonia, $4.95 \mathrm{mM}$.

${ }^{4} \mathrm{DM}, 26.5 \%$ (as fed); and OM, 88.2\%; NDF, $46.9 \%$; indigestible NDF, $12.2 \%$; starch, $1.21 \%$; CP, $21.1 \%$ (DM basis); fermentation $=\mathrm{pH}, 4.63$; acetic acid, $3.36 \%$ of DM; ammonia, $5.09 \mathrm{mM}$.

${ }^{5} \mathrm{DM}, 31.4 \%$ (as fed); and OM, 88.4\%; NDF, 45.2\%; indigestible NDF, $11.6 \%$; starch, $1.24 \%$; CP, $20.5 \%$ (DM basis); fermentation $=\mathrm{pH}, 4.69$; acetic acid, $5.26 \%$ of DM; ammonia, $4.84 \mathrm{mM}$.

${ }^{6}$ West Central Soy Cooperative (Ralston, IA).

${ }^{7}$ Alfalfa $=$ vitamin mineral mix contained (DM basis) $17.7 \%$ sodium bicarbonate, $3.9 \%$ dicalcium phosphate, $2.6 \%$ magnesium oxide, $1.9 \%$ salt, $1.9 \%$ trace mineral premix, $0.4 \%$ vitamin $\mathrm{A}, 0.4 \%$ vitamin $\mathrm{D}, 0.2 \%$ vitamin $\mathrm{E}$, and $71.6 \%$ dry ground corn grain as a carrier.

${ }^{8}$ Orchardgrass $=$ vitamin mineral mix contained (DM basis), $16.5 \%$ sodium bicarbonate, $14.2 \%$ magnesium sulfate, $7.1 \%$ salt, $5.8 \%$ dicalcium phosphate, $2.4 \%$ trace-mineral premix, $0.4 \%$ vitamin $\mathrm{A}, 0.4 \%$ vitamin $\mathrm{D}$, $0.2 \%$ vitamin $\mathrm{E}$, and $53.1 \%$ dry ground corn as a carrier.

${ }^{9}$ Sum of the molar concentrations of nicotinic acid and nicotinamide; expressed as niacin equivalents.

${ }^{10}$ Sum of the molar concentrations of pyridoxamine, pyridoxal, and pyridoxine; expressed as pyridoxine equivalents. 
Table 2. B-vitamin concentrations $(\mathrm{mg} / \mathrm{kg}$ of $\mathrm{DM})$ of ingredients used in the experimental diets containing alfalfa or orchardgrass silages, both chopped to long or short particles ${ }^{1}$

\begin{tabular}{|c|c|c|c|c|c|c|c|}
\hline \multirow[b]{2}{*}{ Vitamin } & \multicolumn{2}{|c|}{ Alfalfa } & \multicolumn{2}{|c|}{ Orchardgrass } & \multirow[b]{2}{*}{ Corn ground } & \multirow[b]{2}{*}{$\mathrm{SBM} 48^{2}$} & \multirow[b]{2}{*}{ SoyPlus ${ }^{3}$} \\
\hline & Long & Short & Long & Short & & & \\
\hline \multicolumn{8}{|l|}{$\overline{\text { Alfalfa }}$} \\
\hline Thiamine & 3.51 & 2.60 & - & - & 4.21 & 4.69 & 1.15 \\
\hline Riboflavin & 148 & 132 & - & - & 15.9 & 25.5 & 43.0 \\
\hline Niacin $^{4}$ & 188 & 170 & - & - & 29.4 & 39.5 & 82.5 \\
\hline Vitamin $\mathrm{B}_{6}{ }^{5}$ & 12.7 & 10.49 & - & - & 3.82 & 4.31 & 2.11 \\
\hline Folates & 0.342 & 0.212 & - & - & 0.081 & 1.85 & 1.01 \\
\hline Vitamin $B_{12}$ & 0.009 & 0.004 & - & - & 0.001 & 0.002 & 0.002 \\
\hline \multicolumn{8}{|l|}{ Orchardgrass } \\
\hline Thiamine & - & - & 1.46 & 1.63 & 4.61 & 4.11 & 2.25 \\
\hline Riboflavin & - & - & 75.6 & 131 & 8.2 & 41.4 & 34.8 \\
\hline $\mathrm{Niacin}^{4}$ & - & - & 52.4 & 77.4 & 14.3 & 54.6 & 44.0 \\
\hline Vitamin $\mathrm{B}_{6}{ }^{5}$ & - & - & 5.8 & 15.2 & 3.6 & 3.9 & 2.2 \\
\hline Folates & - & - & 0.349 & 0.211 & 0.082 & 1.21 & 1.53 \\
\hline Vitamin $B_{12}$ & - & - & 0.007 & 0.016 & 0.005 & 0.006 & 0.006 \\
\hline
\end{tabular}

Data were analyzed separately for the 2 feeding trials. Daily intake, DF, and ARS for each vitamin, expressed in milligram per day or milligram per kilogram of DMI, were analyzed using the MIXED procedure of SAS (version 9.2; SAS Institute Inc., 2008). The hypothesis was tested using the following model:

$$
\mathrm{Y}_{\mathrm{ijk}}=\mu+\mathrm{C}_{\mathrm{i}}+\mathrm{P}_{\mathrm{j}}+\mathrm{T}_{(\mathrm{k})}+\mathrm{PT}_{(\mathrm{jk})}+\varepsilon_{\mathrm{ijk}},
$$

where $Y_{i j k}$ is the dependent variable, $\mu$ is the overall mean, $\mathrm{C}_{\mathrm{i}}$ is the random effect of cow ( $\mathrm{i}=1$ to 13 , trial $1 ; 1$ to 15 , trial 2), $\mathrm{P}_{\mathrm{j}}$ is the fixed effect of period $(\mathrm{j}=1$ to 2$), T_{(\mathrm{k})}$ is the fixed effect of treatment ( $\mathrm{k}=1$ to 2 ), $\mathrm{PT}_{(\mathrm{jk})}$ is the interaction of period and treatment, and $\varepsilon_{\mathrm{ijk}}$ is the residual error. Pearson correlation coefficients were determined using combined data from both experiments. Differences were declared significant at $P<$ 0.05 , and as a tendency at $0.05 \leq P \leq 0.10$.

\section{RESULTS AND DISCUSSION}

Animal performance was presented and discussed previously by Kammes et al. (2012, trial 1, alfalfa treatments) and Kammes and Allen (2012, trial 2, orchardgrass treatments). Particle length did not affect DMI [trial 1: 26.3 vs. $27.2(\mathrm{SE} 0.5 ; P=0.10) \mathrm{kg} / \mathrm{d}$; trial 2: 21.8 vs. 22.7 (SE $0.9 ; P=0.06) \mathrm{kg} / \mathrm{d}$; for $\mathrm{LC}$ and $\mathrm{SC}$, respectively] or DF of DM [trial 1: 15.6 vs. 16.1 (SE $0.6 ; P=0.41) \mathrm{kg} / \mathrm{d}$; trial $2: 12.1$ vs. 12.0 (SE $0.78 ; P=$ $0.96) \mathrm{kg} / \mathrm{d}$; for LC and SC, respectively].
In both trials, differences of B-vitamin concentrations between experimental diets were explained by vitamin concentrations in silages even when forages were not the main source of vitamin in the TMR (i.e., thiamine and folates).

\section{Daily Intake, Apparent Ruminal Synthesis, and Duodenal Flow}

In trial 1, LC increased daily intakes of all $\mathrm{B}$ vitamins, and decreased ARS of thiamine, riboflavin, vitamin $\mathrm{B}_{6}$, and folates. Differences in PL affected only the supply of vitamin $\mathrm{B}_{6}$ to the duodenum $(P<0.04$; Table 3). However, LC increased DF of vitamin $\mathrm{B}_{6}$ and folates when expressed as a proportion of DMI in trial $1(P<0.01$; Table 4$)$. In trial 2 , except for folates, LC decreased vitamin intakes, increased ARS of riboflavin, niacin, and vitamin $\mathrm{B}_{6}$, but only tended to increase folate $\mathrm{DF}(P<0.10$; Table 3$)$.

Alfalfa LC and orchardgrass SC silages had higher DM concentration than SC alfalfa and LC orchardgrass, respectively. This difference was due to the longer wilting time, as the silages were sequentially harvested and SC alfalfa and LC orchardgrass were chopped and ensiled first after mowing (Kammes and Allen, 2012; Kammes et al., 2012). However, this longer wilting time seems to have reduced the B-vitamin concentrations (except folates) in both silages (Table 2), possibly due to a longer exposure to light and heat; riboflavin, for example, has been reported to be destroyed by sundrying (Combs, 2012). In the present trials, reducing 
Table 3. Intake, duodenal flow, and apparent ruminal synthesis (ARS) of B vitamins (mg/d) in response to diets containing alfalfa or orchardgrass silages, both chopped to long or short particles ${ }^{1}$

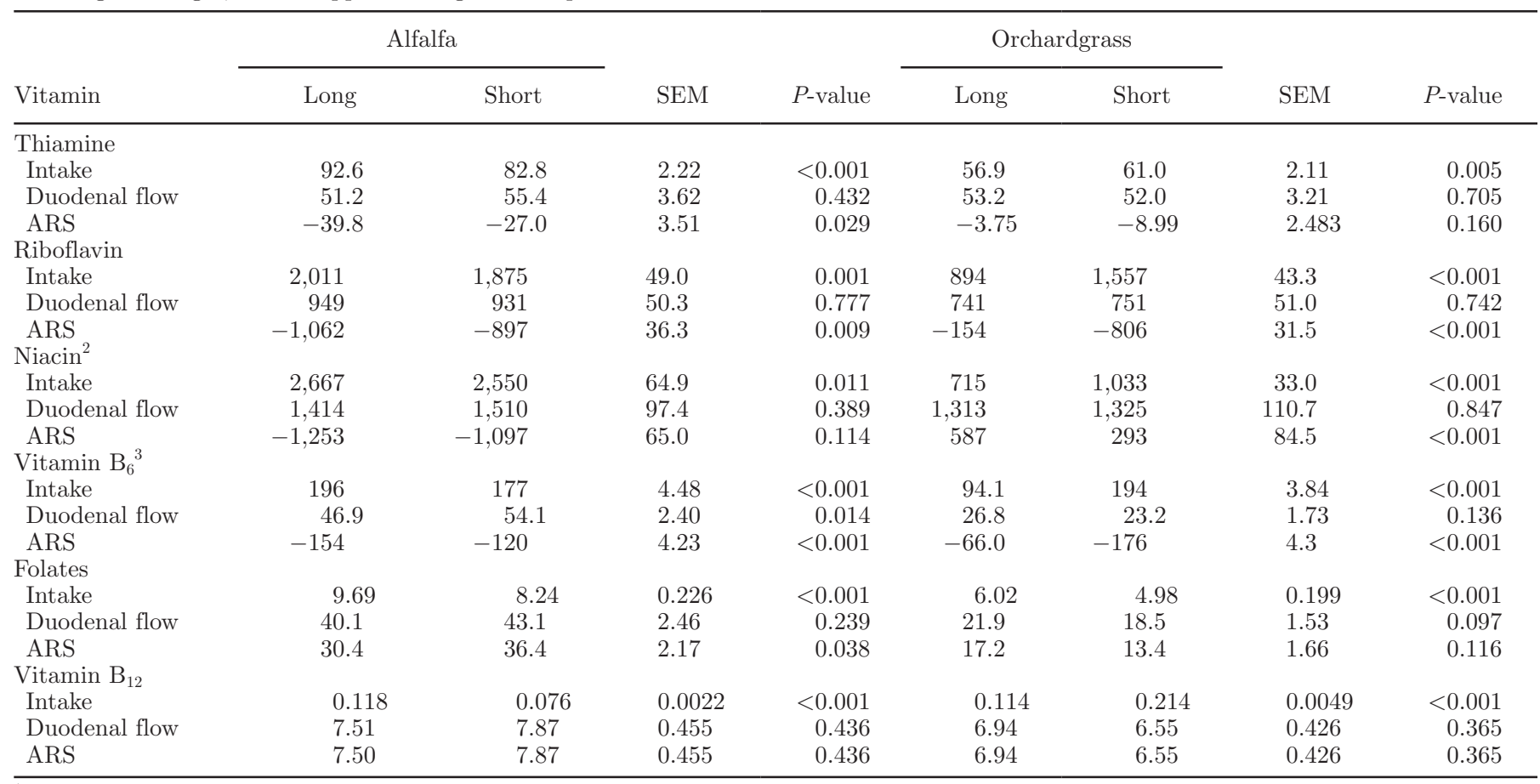

${ }^{1}$ Alfalfa (long $=14.1 \mathrm{~mm}$; short $=8.1 \mathrm{~mm}$ ); orchardgrass (long $=15.3 \mathrm{~mm}$; short $=13.3 \mathrm{~mm}$ ).

${ }^{2}$ Sum of the molar concentrations of nicotinic acid and nicotinamide; expressed as niacin equivalents.

${ }^{3}$ Sum of the molar concentrations of pyridoxamine, pyridoxal, and pyridoxine; expressed as pyridoxine equivalents.

PL increased acetic acid and reduced ammonia concentration in silages from both forage families. However, because increasing PL increased B-vitamin content in trial 1 but had the opposite effect in trial 2 (except for folates), B-vitamin content in silages does not seem to be linked to fermentation conditions in silos.

Table 4. Duodenal flow and apparent ruminal synthesis (ARS) of B vitamins (mg/kg of DMI) in response to diets containing alfalfa or orchardgrass silages, both chopped to a long or short particules ${ }^{1}$

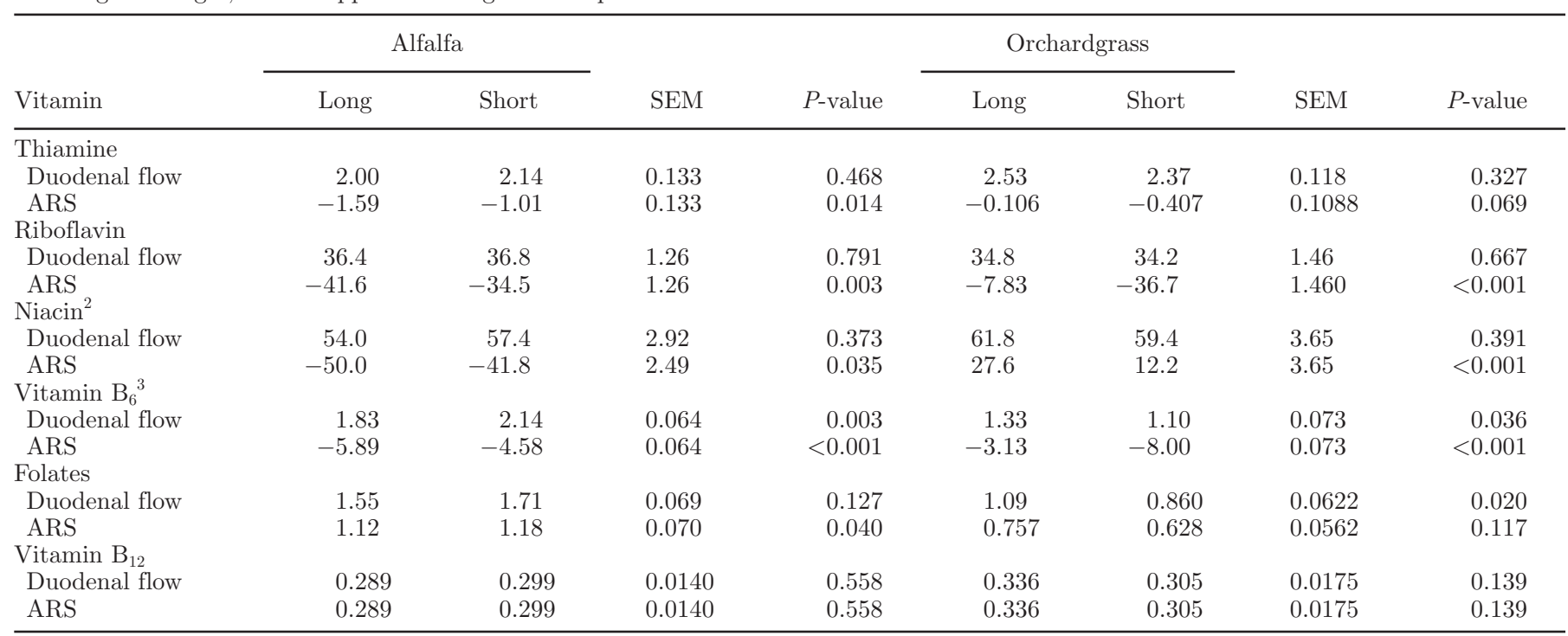

${ }^{1}$ Alfalfa (long $=14.1 \mathrm{~mm}$; short $\left.=8.1 \mathrm{~mm}\right)$; orchardgrass $($ long $=15.3 \mathrm{~mm}$; short $=13.3 \mathrm{~mm})$.

${ }^{2}$ Sum of the molar concentrations of nicotinic acid and nicotinamide; expressed as niacin equivalents.

${ }^{3} \mathrm{Sum}$ of the molar concentrations of pyridoxamine, pyridoxal, and pyridoxine; expressed as pyridoxine equivalents. 
In our study, thiamine ARS varied from -1.59 to $-0.11 \mathrm{mg} / \mathrm{kg}$ of DMI and were similar to values reported by Castagnino et al. $(2016 ;-1.41$ to $-0.83 \mathrm{mg} /$ $\mathrm{kg}$ of DMI) studying similar diets. Apparent ruminal synthesis of thiamine was negative in all treatments, indicating possibly degradation by thiaminases, as suggested by Edwin and Jackman (1982), which may be directly related to ruminal $\mathrm{pH}$ (Brent, 1976). Castagnino et al. (2016) reported a positive correlation between ruminal $\mathrm{pH}$ and thiamine ARS and similar degradation. However, as observed in our study (Table 5), Schwab et al. (2006) reported a negative correlation between thiamine ARS and ruminal $\mathrm{pH}$, whereas Beaudet et al. (2016) did not find any correlation between those parameters. Obviously, ruminal $\mathrm{pH}$ was not the only factor affecting thiamine degradation. However, to our knowledge, little information is available on the fate of thiamine in the rumen. In trial 1, SC decreased ruminal degradation of thiamine whereas an opposite trend was found in trial 2, when ARS was reported per kilogram of DMI.

Reducing PL increased riboflavin ARS in trial 1, but for thiamine, the opposite was observed in trial 2. On average, the amount of riboflavin apparently degraded in the rumen $(36 \mathrm{mg} / \mathrm{kg}$ of DMI) was very similar to the values reported by Castagnino et al. (2016; $35 \mathrm{mg} /$ $\mathrm{kg}$ of DMI) in studies using diets with similar ingredient and nutrient compositions.

Daily niacin DF was similar to values reported by Castagnino et al. (2016), but was only half the values reported by Schwab et al. (2006) and Niehoff et al. (2013). Ruminal microorganisms degraded around $50 \%$ of the dietary niacin in trial 1 with alfalfa treatments, whereas they synthesized between 28 and $82 \%$ of niacin intake in trial 2 with grass treatments. As for thiamine and riboflavin, both trials presented similar DF of niacin. Moreover, individual ARS of these 3 vitamins was negatively correlated with their respective intake. Castagnino et al. (2016) reported similar values of niacin ARS (ranged from 52 to $61 \%$ of niacin intake) in grass treatment, whereas alfalfa treatment also presented positive ARS (ranged from 73 to $157 \%$ of niacin intake). However, niacin intake from diets based on alfalfa silage reported by those authors was, on average, less than the half amount observed in our trial (797 vs. 2,609 mg/d). Such results suggest a mechanism of regulation; it is possible that ruminal microorganisms adjust synthesis or degradation of these vitamins

Table 5. Pearson correlations coefficients between apparent ruminal synthesis $(\mathrm{mg} / \mathrm{d})$ and dietary and digestive parameters combining data from both experiments

B-vitamin apparent ruminal synthesis

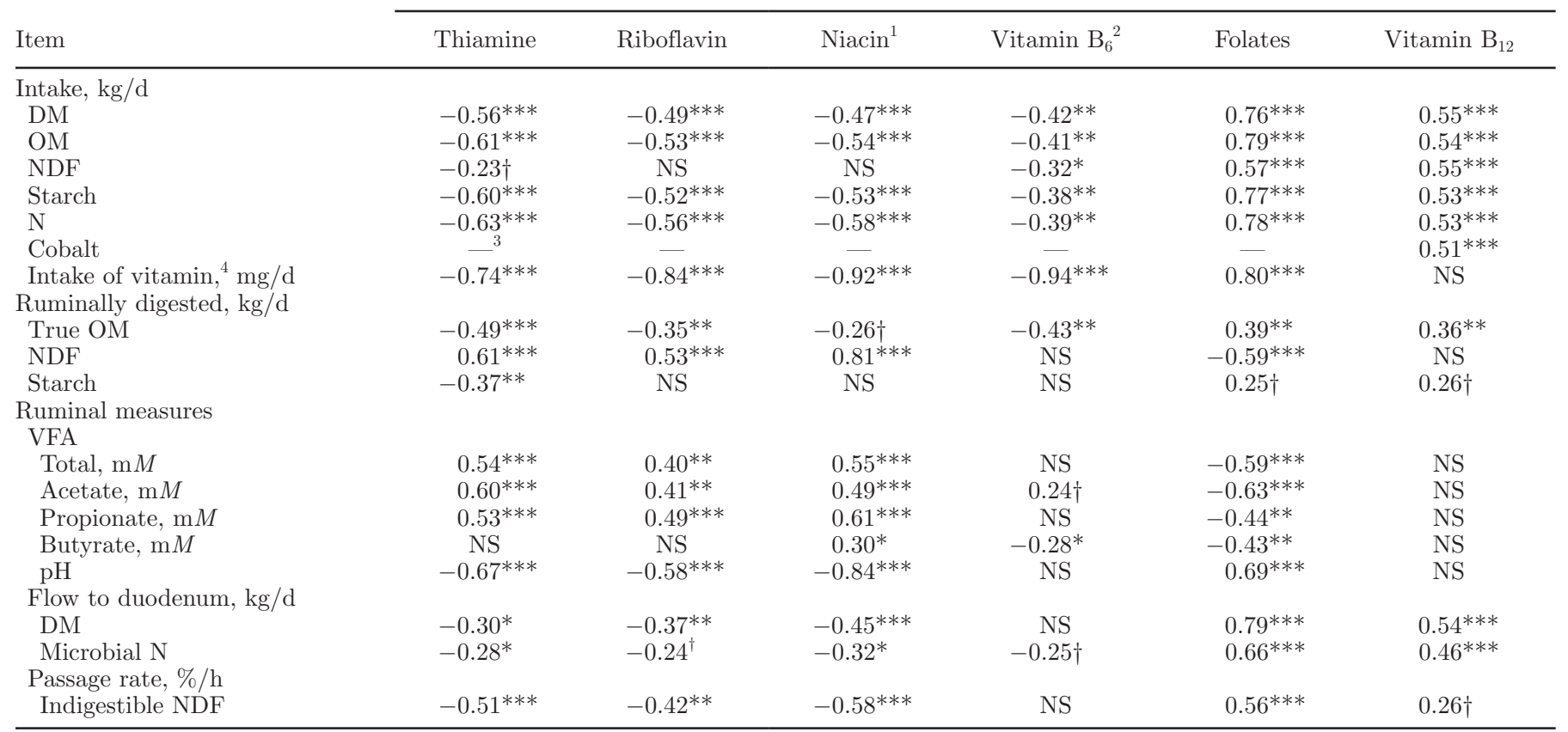

${ }^{1}$ Sum of the molar concentrations of nicotinic acid and nicotinamide; expressed as niacin equivalents.

${ }^{2}$ Sum of the molar concentrations of pyridoxamine, pyridoxal, and pyridoxine; expressed as pyridoxine equivalents.

${ }^{3}$ Not calculated.

${ }^{4}$ Intake of the corresponding B vitamin.

NS, $P \geq 0.10 ; \dagger P<0.10 ; * P<0.05 ; * * P<0.01 ; * * * P<0.001$. 
according to their needs, which depend on microbial mass, microorganism populations, and quantity and quality of substrate.

Similar to our study, Santschi et al. (2005; -0.71 $\mathrm{mg} / \mathrm{kg}$ of DMI), Castagnino et al. (2016; ranging from -1.34 to $-13.3 \mathrm{mg} / \mathrm{kg}$ of $\mathrm{DMI})$, and Beaudet et al. (2016; ranging from -5.64 to $-7.65 \mathrm{mg} / \mathrm{kg}$ of DMI) also observed negative ARS of vitamin $\mathrm{B}_{6}$. As reported for thiamine, riboflavin, and niacin, increasing vitamin $\mathrm{B}_{6}$ dietary supply resulted in greater ruminal degradation. In contrast, however, intake of this vitamin affected DF in both trials.

Reducing silage PL decreased dietary folate supply in both trials, possibly because the greater surface area of short compared with long particles increased the susceptibility of this vitamin to oxidation in the field or to bacterial degradation in the silo. Whereas short particles increased folate synthesis in trial 1 , resulting in a similar DF (on average, $1.6 \mathrm{mg} / \mathrm{kg}$ of DMI), in trial 2, PL did not affect folate ARS, increasing folate DF due to a greater intake of this vitamin with the LC treatment. In contrast to thiamine, riboflavin, niacin, and vitamin $\mathrm{B}_{6}$, folate $\mathrm{ARS}$ was positively correlated with its intake, ruminal $\mathrm{pH}$, and $\mathrm{DM}$ flow to the duodenum, whereas it was negatively correlated with total VFA. However, Hayes et al. (1966) and Schwab et al. (2006) reported a negative correlation between folate ARS and ruminal pH, whereas Castagnino et al. (2016) did not find any relation between both parameters.

The presence of vitamin $B_{12}$ in diets, unlike other $\mathrm{B}$ vitamins, is only from bacterial synthesis occurring during silage fermentation or from contamination by soil microorganisms (McDowell, 2000). The intake of this vitamin was negligible, corresponding to less than $2 \%$ of its DF. Particle length of forages, in the studied range, did not affect the ARS or the supply of vitamin $\mathrm{B}_{12}$ reaching the intestinal sites of absorption. Daily vitamin $B_{12}$ ARS was similar to values reported by Castagnino et al. (2016; $0.5 \mathrm{mg} / \mathrm{kg}$ of DMI), but much less than those reported by Santschi et al. (2005; 3.69 $\mathrm{mg} / \mathrm{kg}$ of DMI) and Schwab et al. (2006; $3.93 \mathrm{mg} / \mathrm{kg}$ of DMI). Cobalt is an essential component of the vitamin $\mathrm{B}_{12}$. In both trials, dietary concentrations of this mineral were greater than recommendations for dairy cows proposed by NRC $(2001 ; 0.11 \mathrm{mg} / \mathrm{kg}$ of DM). Nevertheless, the strong positive correlation between vitamin $\mathrm{B}_{12}$ ARS and cobalt concentration in the rumen may indicate that this recommended dietary concentration was not adequate to support optimal ruminal synthesis of vitamin $\mathrm{B}_{12}$.

In both trials, ingredient and nutrient composition of experimental diets were similar, the only difference being silage PL. It is noteworthy that ARS of thiamine, riboflavin, and niacin were all negatively correlated with nutrient intake, ruminal $\mathrm{pH}$, passage rates of $\mathrm{DM}$, and indigestible NDF in rumen, and DF of microbial $\mathrm{N}$ but positively correlated with the amount of NDF digested in rumen, and ruminal concentrations of VFA. These observations suggested that greater nutrient intake and digesta DF as well as lower NDF digestion in the rumen increased apparent degradation of thiamine, riboflavin, and niacin by rumen bacteria. To a lesser extent, vitamin $\mathrm{B}_{6}$ ARS followed a similar pattern.

Daily folate ARS was positively correlated with nutrient intakes (DM, OM, NDF, starch, and nitrogen), ruminal $\mathrm{pH}$ and $\mathrm{DM}$ flow to the duodenum, but negatively correlated with total VFA, suggesting that conditions promoting folate ARS had the opposite effects on thiamine, riboflavin, niacin, and vitamin $\mathrm{B}_{6}$ ARS. As for folates, ARS of vitamin $B_{12}$ was positively correlated with nutrient intakes and microbial $\mathrm{N}$ flow to duodenum, which indicates that vitamin $\mathrm{B}_{12}$ ARS is closely linked to microbial biomass activity. Similar correlations were reported by Castagnino et al. (2016).

\section{CONCLUSIONS}

Within each trial, the ingredients and their proportions were similar for both treatments, the only difference being alfalfa or orchardgrass silage PL. In both trials, differences in vitamin intakes were due to the concentrations of these vitamins in silages. Under the conditions of the current experiment, harvesting seems to have a greater effect on B-vitamin concentrations in silages than fermentation conditions in silos. Increasing wilting time appears to have reduced B-vitamin concentrations in both trials, except for folates in orchardgrass silages. Except for vitamin $\mathrm{B}_{12}$, ARS of studied $B$ vitamins were affected by PL. Nevertheless, these differences in intakes and ARS had no or only limited effects on the amounts of these vitamins reaching the sites of absorption in the small intestine. Ruminal synthesis of B vitamins involves complex and dynamic processes that interact with several dietary factors and rumen fermentation conditions. More research with a wide range of treatments is needed to increase our understanding of B-vitamin synthesis and to predict their DF, to estimate the amounts available for the animal, and ultimately to establish the need for dietary supplementation.

\section{ACKNOWLEDGMENTS}

The authors thank Chrystiane Plante (Agriculture and Agri-Food Canada, Sherbrooke, QC, Canada) for her technical support. The Programme de recherche en partenariat pour l'innovation en production et transformation laitière Novalait-Agriculture et Agroalimen- 
taire Canada-Fonds de recherche du Québec Nature et Technologies-Ministère de l'Agriculture, des Pêcheries et de l'Alimentation du Québec, Québec, Canada, financially supported a grant for the $\mathrm{PhD}$ student and vitamin analyses.

\section{REFERENCES}

Beauchemin, K. A., W. Z. Yang, and L. M. Rode. 2003. Effects of particle size of alfalfa-based dairy cow diets on chewing activity, ruminal fermentation, and milk production. J. Dairy Sci. 86:630-643. http://dx.doi.org/10.3168/jds.S0022-0302(03)73641-8.

Beaudet, V., R. Gervais, B. Graulet, P. Nozière, M. Doreau, A. Fanchone, D. S. Castagnino, and C. L. Girard. 2016. Effects of dietary nitrogen levels and carbohydrate sources on apparent ruminal synthesis of some B vitamins in dairy cows. J. Dairy Sci. 99:2730 2739. http://dx.doi.org/10.3168/jds.2015-10521.

Bellanger, J. 1988. Détermination du cobalt-EDTA dans les contenus duodénaux. Reprod. Nutr. Dev. 28:103-104. http://dx.doi. org/10.1051/RND:19880114.

Brent, B. E. 1976. Relationship of acidosis to other feedlot ailments. J. Anim. Sci. 43:930-935.

Castagnino, D. S., K. L. Kammes, M. S. Allen, R. Gervais, P. Y. Chouinard, D. E. Santschi, and C. L. Girard. 2014. Apparent synthesis of thiamin and vitamin B12 in rumen of lactating dairy cows fed alfalfa or orchardgrass silages at different maturity stages. J. Dairy Sci. 97(E-Suppl. 1):1876.

Castagnino, D. S., M. Seck, V. Beaudet, K. L. Kammes, J. A. Voelker Linton, M. S. Allen, R. Gervais, P. Y. Chouinard, and C. L. Girard. 2016. Effects of family forage on apparent ruminal synthesis of B vitamins in lactating dairy cows. J. Dairy Sci. 99:1884-1894. http://dx.doi.org/10.3168/jds.2015-10319.

Combs, G. F., Jr. 2012. The Vitamins. 4th ed. Elsevier Incorporated, New York, NY.

Dixon, R. M., and L. P. Milligan. 1985. Removal of digesta components from the rumen of steers determined by sieving techniques and fluid, particulate and microbial markers. Br. J. Nutr. 53:347362. http://dx.doi.org/10.1079/BJN19850042.
Edwin, E. E., and R. Jackman. 1982. Ruminant thiamine requirement in perspective. Vet. Res. Commun. 5:237-250. http://dx.doi org/10.1007/BF02214990.

Hayes, B. W., G. E. Mitchell, C. O. Little, and N. W. Bradley. 1966. Concentrations of B vitamins in ruminal fluid of steers fed different levels and physical forms of hay and grains. J. Anim. Sci $25: 539-542$.

Kammes, K. L., and M. S. Allen. 2012. Nutrient demand interacts with grass particle length to affect digestion responses and chewing activity in dairy cows. J. Dairy Sci. 95:807-823. http://dx.doi. org/10.3168/jds.2011-4588.

Kammes, K. L., Y. Ying, and M. S. Allen. 2012. Nutrient demand interacts with legume particle length to affect digestion responses and rumen pool sizes in dairy cows. J. Dairy Sci. 95:2616-2631. http://dx.doi.org/10.3168/jds.2011-4906.

McDowell, L. R. 2000. Vitamins in Animal and Human Nutrition. 2nd ed. Iowa State University Press, Ames.

Niehoff, I. D., L. Hüther, P. Lebzien, and G. Flachowsky. 2013. The effect of a niacin supplementation to different diets on ruminal fermentation and flow of nutrients to the duodenum of dairy cows. Landbauforsc. Appl. Agric. Forestry Res 63:143-154. http:// dx.doi.org/10.3220/LBF_2013_143-154.

NRC. 2001. Nutrient Requirements of Dairy Cattle. 7th rev. ed. The Natl. Acad. Press, Washington, DC.

Santschi, D. E., R. Berthiaume, J. J. Matte, A. F. Mustafa, and C. L. Girard. 2005. Fate of supplementary B-vitamins in the gastrointestinal tract of dairy cows. J. Dairy Sci. 88:2043-2054. http://dx.doi org/10.3168/jds.S0022-0302(05)72881-2.

SAS Institute Inc. 2008. User's Guide: Statistics. Version 9.2. SAS Institute Inc., Cary, NC.

Schwab, E. C., C. G. Schwab, R. D. Shaver, C. L. Girard, D. E Putnam, and N. L. Whitehouse. 2006. Dietary forage and nonfiber carbohydrate contents influence B-vitamin intake, duodenal flow, and apparent ruminal synthesis in lactating dairy cows. J. Dairy Sci. 89:174-187. http://dx.doi.org/10.3168/jds.S00220302(06)72082-3

Van Soest, P. J. 1982. Nutritional Ecology of the Ruminant. O \& B Books Inc., Corvallis, OR.

Zinn, R. A., F. N. Owens, R. L. Stuart, J. R. Dunbar, and B. B. Norman. 1987. B-vitamin supplementation of diets for feedlot calves. J. Anim. Sci. 65:267-277. 